\title{
Preliminary List of the Insects of Desecheo Island, Puerto Rico ${ }^{1}$
}

\author{
José C. Garcia Tudurí, Silverio Medina Gaud and Luis F. Martorell ${ }^{2}$
}

\section{INTRODUCTYON}

Desecheo is a small rocky island of about 640 acres located in the Mona Passage, about 12 miles west of Punta Jigüero on the extreme western coast of Puerto Rico, latitude $182^{\prime}$ North and longitude $672^{\prime}$ West. Its highest peak is 676 feet according to photogrametric calculations. Notes on the geology, origin of the name and a historical account of the scientific explorations of this island were given by Woodbury et al. (23).

The island has been little studied entomologically because of the extremely rugged and brushy terrain. Even light traps are difficult to operate because visibility is hampered by dense and tall vegetation. Trap placement in favorable locations is nearly impossible because steep hillsides prevent the use of motorized equipment such as generators and extension wires.

The first insect records from the island probably are those of the American entomologists H. G. Barber, H. E. Crampton, F. F. Lutz, A. J. Mutchler and F. E. Watson, who visited Desecheo and adjacent Mona, collecting in the first locality Feb. 18-20, 1914.

Dr. Stuart T. Danforth, professor of Zoology and Entomology at the College of Agriculture and Mechanic Arts at Mayaguiez, accompanied by some students, spent May 7-9, 1927 on Desecheo for the purpose of making ornithological investigations. The results of this visit were published in the Journal of Agriculture of Puerto Rico (7), together with several records pertaining to insects.

Recent visits have been made to the island, for the particular purpose of studying its flora. Some entomological observations were also made. George W. Miskimen, Luis F. Martorell, and Clyde F. Smith, entomologists; and Dario Galindez, a Colombian student in entomology and Roy Woodbury, plant taxonomist, visited the island April 5, 1967. A second visit was made July 12-14, 1968 by Roy Woodbury, Luis F. Martorell, J. García Tuduri, Silverio Medina Gaud and Kim Woodbury to collect plants and insects. A third and last visit was made Dec. 6-7, 1971 by Roy Woodbury, Luis F. Martorell, J. García Tuduri, H. Gandía-Díaz, J. Ser-

1 Manuscript submitted to Editorial Board August 1, 1973.

2 Assistant Entomologist, Associate Entomologist and Professor Emeritus, respectively, Agricultural Experiment Station, Mayagüez Campus, University of Puerto Rico, Río Piedras, P.R. 
rallés and Herbert Raffaele to collect insects, spiders and plants. Raffaele made ornithological observations.

The authors are aware that much more collecting is needed on Desecheo. This preliminary list may serve however, as a starting point for others who will continue entomological investigations there.

Unless otherwise indicated, names of collectors are indicated by initials in parenthesis, thus (LFM) for Luis F. Martorell, (JGT) for Jose C. García Tuduri, and (SMG) for Silverio Medina Gaud.

\section{LIST OF INSECTS}

ORDER COLEOPTERA

\section{Family Cicindelidae}

1. Cicindela trifasciata Fabr. - Specimens fairly common along the sandy beach at Puerto de los Botes Dec. 6, 1971 (LFM).

\section{Family Buprestridae}

2. Polycesta porcata (Fabr.)-Larvae of this Hispanolian species were found boring in branches and twigs of unidentified shrubs Dec. 6, 1971 (LFM and JGT).

\section{Family Cantharidae}

3. Tytthonyx discolor Leng \& Mutchler.-Originally described by Leng \& Mutchler (12) from specimens collected at Aibonito and Desecheo Island in 1914 by Frank E. Lutz. It is an elongate little black beetle with elytra only partly covering the abdomen. The type from Aibonito is $3.25 \mathrm{~mm}$ long, but other specimens from Desecheo are smaller, 2.5 to $2.75 \mathrm{~mm}$ in length, and paler throughout, being dark brown rather than black. The Lutz record was cited later by Wolcott $(22,23)$.

\section{Family Coccinellidae}

4. Cycloneda sanguinea (Linn.)-Specimens found abundant among branches of shrubs and smaller plants Dec. 6, 1971 (LFM and JGT).

\section{Family Tenebrionidae}

5. Phaleria angustata Chevrolat.-Specimens collected Dec. 6, 1971 (LFM and JGT).

6. Tenebrio molitor $\mathrm{L}$.-Recorded by Wolcott $(22,23)$ from one specimen collected May 1927 by Stuart T. Danforth.

7. Aphthona compressa Suffrian.-Recorded by Gundlach (9), Leng and Mutchler (12) and by Wolcott (21) from Aibonito and Desecheo Island. 
8. Homoschema nigriventre Blake. Specimens abundant and attacking the foliage of Stygmaphyllon periplocifolium Dec. 6, 1971 (LFM and JGT).

\section{Family Oedemeridae}

9. Copidita (Asclera) desecheonis Wolcott.-Species reported by Ramos (18) as Copida (Asclera) sp. b. as determined by J. M. Valentine. Species designated by Wolcott (22) from specimens found very abundant on Desecheo Island May 8, 1927 by Stuart T. Danforth, and determined by A. J. Mutchler as an undescribed species of Ditylus. Wolcott (22) states "Because of this first collection, it might be well to designate these beetles as Copidita (Asclera) desecheonis)."

ORDER DERMAPTERA

\section{Family Labiduridae}

10. Anisolabis maritima (Bonelli).-Specimens collected Dec. 6, 1971 under carton boxes near the seashore in a shady situation in a cave under a large rock (LFM and JGT).

ORDER DIPTERA

\section{Family Cecidomyiidae}

11. Ctenodactylomyia watsoni Felt.-Observed Dec. 6, 1971 by L. F. Martorell causing cone-shaped galls on the leaves of many Coccoloba uvifera trees at the southwestern portion of the Island close to the heliport. This pest is very common on the same host in Puerto Rico and on Mona Island.

\section{Family Stratiomyidae}

12. Cyphomyia chalybea (Wied.).-Adults collected July 13, 1968 on Citharexylum fruticosum and larvae collected same date in rotten Opuntia dilleni; adults emerged about two months later (SMG). Also recorded by James (11).

13. Cyphomyia lasiophthalma Williston.-Recorded by Wolcott $(21,22)$ from various localities and Desecheo from specimens collected May 1927 by Stuart T. Danforth.

\section{Family Syrphidae}

14. Volucella unipunctata Curran.-Described by Curran (5) and cited by him (6) from specimens collected at Desecheo and Ensenada; it also has been found at Coamo. Cited by Wolcott $(21,22)$ as $V$. unipuncta. 


\section{Family Micropezidae}

15. Haplocheiloma fabricii Steyskal.-Five specimens collected July 13, 1968 on goat feces (SMG). Recorded as a new record for Puerto Rico by Medina and Martorell (16).

\section{Family Otitidae}

16. Notogramma stigma (Fabr.).-Recorded by Curran (6) and cited by Wolcott $(21,22)$. Larvae collected July 13, 1968 on rotten Opuntia dilleni pads; they pupated July 15, 1968 and adults emerged August 4, 1968 (SMG).

\section{Family Milichidae}

17. Desmometopa tarsalis Loew.-Recorded by Curran (6) from a single specimen collected in 1914 by Frank E. Lutz. This is the record cited by Wolcott $(21,22)$.

18. Milichiella arcuata (Loew).--Recorded by Curran (6) from a single male specimen collected in 1914 by Frank E. Lutz as cited by Wolcott $(20,22)$.

19. Milichiella lacteipennis (Loew).-Described as Desmometops halteralis by Coquillet (4). Recorded from Desecheo and the name synonymized by Curran (6) from specimens collected in 1914 by Frank E. Lutz as cited by Wolcott $(21,22)$.

\section{Family Ephydridae}

20. Leptopsilopa nigrimana (Williston).-Recorded by Coquillet (4) as Psilopa nigrimana Williston and by Curran (5) as Leptopsilopa willistoni Cresson. Wolcott $(5,6)$ recorded it as Leptopsilopa willistoni Cresson and as Leptopsilopa nigrimana (Williston), respectively.

\section{Family Drosophilidae}

21. Drosophila (Drosophila) mulleri Sturtevant.-Recorded as a new record for Puerto Rico by Medina and Martorell (16) from larvae collected on rotten pads of Opuntia dillenii July 13, 1968, the adults emerging Aug. 12, 1968 (SMG).

\section{Family Chloropidae}

22. Hippelates impressus Becker.-Recorded by Curran (6) from specimens collected in 1914 by Frank E. Lutz as cited by Wolcott $(21,22)$.

\section{Family Muscidae}

23. Musca domestica L.-Specimens collected at the seashore July 13, 1968 (SMG). 


\section{Family Hippoboscidae}

24. Olfersia aenescens C. G. Thomson.-Recorded by Wolcott $(21,22)$ from specimens collected by Stuart T. Danforth from a booby (Sula leucogaster) (bird) May 1927 and identified as Olfersia diomedeae Coquillet by J. M. Aldrich. Subsequently listed by Bequaert (2) as Olfersia erythropsis Bigot, and with corrected name in 1940 (3).

25. Olfersia fossulata Macquart.-Recorded by Bequaert $(2,3)$ from specimens collected by Stuart T. Danforth on booby. Subsequently listed by Wolcott (22).

\section{Family Calliphoridae}

26. Cochliomyia macellaria (Fab.).-Two specimens collected on sandy soil near the seashore July13, 1968 (SMG).

27. Phaenicia eximia (Wiedemann).-Recorded from Desecheo first by Curran (6) as Lucilia hirtiforceps Shannon on the basis of a female collected there in 1914. Shannon's species described originally from Panama, Costa Rica and Mexico is a synonym of eximia according to David G. Hall. Curran's record was cited by Wolcott (21) but corrected to Phaenicia eximia in 1948 (22).

\section{Family Sarcophagidae}

28. Helicobia rapax (Walker).-One specimen collected on sandy soil near the beach July 13, 1968 by S. Medina Gaud. Listed in Wolcott (22) as Sarcophaga (Helicobia) rapax Walker, "apparently a true parasite" of beetles and caterpillars of Remigia repanda (Fabr.), the sugarcane looper.

29. Sarcophaga spp.-Specimens of this genus were collected on sandy soil near the beach July 13, 1968 (SMG).

\section{ORDER HEMIPTERA}

\section{Family Lygaeidae}

30. Nysius basalis Dallas.-Recorded by Wolcott (22). Barber (1) synonymized the name with $N$. inaequalis Uhler. Specimens were collected on Desecheo in 1914 by H. E. Crampton.

31. Paramius longulus (Dallas).-First recorded by Gundlach (9) as Pamera and later as Paramius by Wolcott (22) on the basis of specimens collected on Desecheo and Mona Islands.

\section{Family Coreidae}

32. Niesthrea sidae (Fabr.).-Listed by Gundlach (9) and by more recent authors as Corizus sidae. The species occurs in all parts of Puerto Rico as well as on both Mona and Desecheo. Subsequently recorded by Wolcott 
(22) under the synonym Niesthrea vincentii (Westwood) on the basis of specimens collected in 1914 by Lutz.

\section{ORDER HOMOPTERA}

\section{Family Cicadellidae}

33. Xerophloea viridis (Fabr.).-This species was redescribed by Osborn (17) from specimens at the American Museum of Natural History collected on Desecheo Island in 1914. The same record was cited by Wolcott $(21,22)$.

\section{Family Coccidae}

34. Ceroplastes sp.- Specimens fairly common on branches of Bursera simamiba and Solanum racemosum in the valley north of Puerto de los Botes Dec. 6, 1971 (LFM and JGT).

35. Saissetia coffeae (Walker).-Specimens found abundant on twigs of Eugenia axillaris in a small valley directly north of Puerto de los Botes Dec. 6, 1971 by Roy Woodbury.

\section{ORDER HYMENOPTERA}

\section{Family Scoliidae}

36. Myzine haemorrhoidalis (F.).-Specimens collected among the foliage of bushes Dec. 6, 1971 (LFM and JGT).

\section{Family Formicidae}

37. Camponotus ustus Forel.-Specimens collected in tunnels in old and rotten twigs and branches of shrubs Dec. 6, 1971 (LFM and JGT) and determined by D. R. Smith.

38. Solenopsis globularia desecheoensis Mann.-This variety was described from Desecheo by Mann (13). The ants have a jet black body and yellowish-brown appendages. This record was cited by Wolcott (22).

\section{Family Vespidae}

39. Polistes americanus F.-Adults fairly common flying around shrubs and lower vegetation Dec. 6, 1971 (LFM and JGT).

40. Polistes major Palisot de Beauvois.-Adults abundant about trees and bushes as well as in open areas Dec. 6, 1971 (LFM and JGT).

$$
\text { ORDER IBOPTERA }
$$

\section{Family Kalotermitidae}

41. Procryptotermes corniceps (Snyder).-Alates, soldiers and nymphs abundant in rotten trunks and branches of trees and shrubs Dec. 6, 1971 (LFM and JGT). 
ORDER LEPIDOPTERA

\section{Family Psychidae}

42. Oiketicus kirbyi Guilding.-Specimens of this common, polyphagous bag worm were collected on Desecheo in the foliage of bushes Dec. 6, 1971 (LFM and JGT).

\section{Family Pyraustidae}

43. Dichogamma redtenbacheri Lederer.-One specimen collected on the foliage of an unidentified shrub. The larvae of this species were recorded by Martorell $(14,15)$ as feeding on foliage of Capparis flexuosa and C. portoricensis in Puerto Rico.

\section{Family Phycitidae}

44. Cactoblastis cactorum Berg.-Recorded by García Tuduri, et al. (8). This species is fairly abundant on Desecheo where the larvae attacks various species of cactii (Opuntia dillenii, 0 . triacantha and Consolea moniliformis).

\section{Family Hesperiidae}

45. Wallengrenia otho mutchleri Watson.-This subspecies was described by Watson (20) on the basis of specimens from Puerto Rico, Mona and Desecheo Islands; St. Thomas, St. Croix of the Virgin Islands and Hispaniola, etc. Wolcott (22) cited Watson records.

\section{Family Pieridae}

46. Appias (Glutophrissa) drusilla boydi Comstock.-Many specimens of this species were seen Dec. 6, 1971 (LFM and JGT) but only one was collected. It is a typical species of the xerophytic areas of Puerto Rico and Mona Island.

\section{Family Nymphalidae}

47. Dione vanillae insularis (Maynard).-Wolcott (22) recorded the presumable occurrence of the species on Desecheo. Martorel saw many of these butterflies during his second trip there July 12, 1968 but collected no specimens.

ORDER NEUROPTERA

\section{Family Chrysopidae}

48. Chrysopa sp.-One specimen collected on the foliage of a shrub Dec. 6, 1971 (LFM and JGT). 
ORDFR ORTHOPTERA

\section{Family Blaberidae}

49. Panchlora sp.-One specimen collected Dec. 6, 1971 (LFM and JGT).

50. Pycnoscelus surinamensis (Linn.).-Recorded by Rehn and Hebard (19) from this and other localities in Puerto Rico. Wolcott $(21,22)$ cited Rehn and Hebard records.

\section{Family Blattellidae}

51. Symploce flagellata.-This species was described by Hebard (10) from specimens collected on Desecheo and Mona by F. E. Lutz in 1914. Rehn and Hebard (19) noted the species "does not occur on the island of Puerto Rico itself". Wolcott $(21,22)$ and Ramos $(18)$ cited the previous records.

ORDER THYSANOPTERA

\section{Family Thripidae}

52. Scolothrips sp. near pallidus (Beach).-This species is listed by Medina Gaud and Martorell (16) as a new record for Puerto Rico; it was collected on leaves of Ipomoea triloba July 13, 1968 (SMG).

ORDER THYSANURA

\section{Family Lespismidae}

53. Lepisma saccharina L.-Recorded as occurring on Desecheo in May and Nov. 1927 by Wolcott (22).

\section{SUMMARY}

An annotated list is furnished for the $\mathbf{5 3}$ insect species known to occur on Desecheo Island.

\section{RESUMEN}

En este trabajo se enumeran 53 especies de insectos de la isla de Desecheo y se incluyen algunas notas éntomológicas respecto a esa isla.

\section{LITERATURE CITED}

1. Barber, H. G., A preliminary report on the Hemiptera-Heteroptera of Puerto Rico collected by the American Museum of Natural History, Amer. Mus. Novitates 75: 1-13, 1923.

2. Bequaert, J., Notes on Hippoboscidae-7. A tentative key species of Olfersia Wiedemann (Feronia Leach; Pseudolfersia Coquillet), Psyche 40 (3): 101-5, 1933. 
3. - Notes on Hippoboscidae-17. The Hippoboscidae of the Antilles, Memorias de la Sociedad Cubana de Historia Natural, Habana 14 (4) : 305-27, 1940.

4. Coquillet, D. W., Report on a collection of dipterous insects from Puerto Rico, Proc. U.S. Nat. Mus. 22: 249-70, 1900.

5. Curran, C. H., New Diptera from the West Indies, Amer. Mus. Novitates 220: 1-14, 1926.

6. - Diptera or two-winged flies, Sc. Surv. P.R. and the Virgin Islands, Vol. II, part 1. Insects of Puerto Rico and the Virgin Islands, N.Y. Acad. Sci., N.Y., pp. 118, 1928.

7. Dandorth, S. T., Puerto Rican ornithological records, J. Dept. Agr. P.R. 15 (1): 33-106, 1931.

8. Garcla Tuduri, J. C., Martorell, L. F., and Medina Gaud, S., Geographical distribution and host plants of the cactus moth, Cactoblastis cactorum (Berg), in Puerto Rico and the United States, Virgin Islands, Res. Note J. Agr. Univ. P.R. 55 (1): 130-4, 1971.

9. Gundlach, J., Apuntes para la Fauna Puerto-Riqueña VIII Insectos, An. Soc. Esp. Hist. Nat. 16: 137-9, 1887.

10. Hebard, M., Studies in the group Ischnopterites, Trans. Amer. Entomol. Soc. 42: 367, 1916.

11. James, M. T., New species and records of Stratiomyidae from the West Indies, Carib. J. Sci. 12 (3-4): 145-50, 1972.

12. Leng, C. W., and Mutchler, A. J., The Lycidae, Lampyridae and Cantharidae (Telephoridae) of the West Indies, Bull. Amer. Mus. Nat. Hist. 46 (8) : 413-99, 1922.

13. Mann, W. M., Additions to the ant fauna of the West Indies and Central America, Bull. Amer. Mus. Nat. Hist. 42 (8) : 428, 1920.

14. Martorell, L. F., A survey of the forest insects of Puerto Rico, Part I, J. Agr. Univ. P.R. 29 (3) : 69-354, 1945.

15. - A survey of the forest insects of Puerto Rico, Part II, J. Agr. Univ. P.R. 29 (4): 355-608, 1945.

16. Medina Gaud, S., and Martorell, L. F., New insect records for Puerto Rico, J. Agr. Univ. P.R. 57 (3): 247-54, 1973.

17. Osborn, H., Insects of Puerto Rico and the Virgin Islands. Homoptera (excepting the Sternorhynchi), Sc. Surv. P.R. and the V.I., N.Y. Acad. Sc. 14 (2): 111-260, 1935.

18. Ramos, J., The insects of Mona Island (West Indies), J. Agr. Univ. P.R. 30 (1): 1-74, 1946.

19. Rehn, J. A. G., and Hebard, M., The Orthoptera of the West Indies, No. 1. Blattidae, Bull. Amer. Mus. Nat. Hist. 54 (1): 320, 1927.

20. Watson, F. W., New Hesperiidae from the Antilles (Lepidoptera: Rhopalocera), Amer. Mus. Novitates No. 906: 1-10, 1937.

21. Wolcott, G. N., Insectae Borinquenses, a revised annotated check-list of the insects of Puerto Rico, J. Agr. Univ. P.R. 20 (1): 1-627, 1936.

22. - Insects of Puerto Rico, J. Agr. Univ. P.R. 32 (1-4): 1-975, 1948.

23. Woodbury, R. C., Martorell, L. F., and Garcia Tuduri, J. C., The flora of Desecheo Island, Puerto Rico, J. Agr. Univ. P.R. 55 (4): 478-505, 1971. 